\title{
Analiza przydatności wybranych złóż gazu ziemnego zapadliska przedkarpackiego do konwersji na PMG
}

\begin{abstract}
Głównym celem prac opisanych w niniejszym artykule było przeprowadzenie analizy możliwości wykorzystania wybranych złóż gazowych zapadliska przedkarpackiego do konwersji na PMG. Ocena została wykonana dla złóż Tuligłowy - horyzont VIII i Jarosław - horyzonty C i D. Przydatność struktur złóż gazu ziemnego do konwersji na podziemny magazyn gazu oceniono pod kątem szczelności, strukturalnym, złożowym i ekonomicznym. Powyższe złoża spełniają wszystkie wymagane kryteria. Wstępna analiza geologiczno-złożowa wykazała, że w każdym z nich można wytworzyć podziemny magazyn gazu. Należy pamiętać, że przedstawiona analiza ma charakter szacunkowy, a ewentualna decyzja o konwersji tych złóż na PMG powinna zostać poprzedzona opracowaniem studium wykonalności.
\end{abstract}

Słowa kluczowe: zapadlisko przedkarpackie, miocen, konwersja, złoże gazu ziemnego.

\section{The suitability analysis of selected gas fields located in the Carpathians depression basin for UGS}

\begin{abstract}
The main aim of this paper was to analyze the possibilities of using selected gas fields Foredeep to convert to UGS. The assessment was made for the submission of Tuligłowy horizon VIII and Jaroslaw horizon C and D. The suitability of natural gas structures to convert to an underground gas storage facility was rated for leaks, structural, and economic reserve sites. These deposits meet all the required criteria. Preliminary geological and reservoir analysis showed that in each of them can be produced an underground gas storage facility. Please note that the analysis is an estimate, and any decision to convert those deposits in the UGS should be preceded by a feasibility study.
\end{abstract}

Key words: Carpathian foreland basin, Miocene, conversion, natural gas field.

\section{Zapadlisko przedkarpackie}

Zapadlisko przedkarpackie na terenie Polski obejmuje obszar około $18000 \mathrm{~km}^{2}$ i zawiera złoża i nagromadzenia wysokometanowego gazu ziemnego. Zapadlisko to, będące rowem przedgórskim powstałym u czoła nasuwających się ku północy Karpat, jest najmłodszą jednostką alpejską na obszarze Polski. Biorąc pod uwagę cechy strukturalne, sedymentologiczne i stratygraficzne, można je podzielić na część wewnętrzną i zewnętrzną oraz zachodnią i wschodnią $[6,7,8]$. Zapadlisko jest wypełnione osadami molasowymi miocenu. Tworzy je zespół nawzajem przeławicających się piaskowców, mułowców i łłowców. Osady mioceńskie mają na tere- nie Polski miąższość do 3500 m i cechują się dużym zróżnicowaniem litologicznym. Sekwencje profilu, gdzie dominują piaskowce i zapiaszczone mułowce, tworzą oddzielne horyzonty gazonośne. Ich liczba w poszczególnych profilach odkrytych złóż gazowych waha się od kilku do 24 na polu gazowym Przemyśl. Początek powstania polskiej części zapadliska, a także wiek najstarszych wypełniających go osadów najprawdopodobniej przypada na eggenburg [9]. Im dalej ku północy, tym wiek najstarszych osadów jest młodszy. Do wczesnego badenu zbiornik morski nie wykraczał poza współczesny zasięg płaszczyzn Karpat zewnętrznych. Zbiornik 
mioceński rozszerzył się ku północy w środkowym badenie, jednakże między wewnętrzną a zewnętrzną jego częścią istniał wypiętrzony obszar zwany wyspą rzeszowską. Na przesuwanie się osi subsydencji w zbiorniku zapadliska największy wpływ miało nasuwanie się płaszczowin Karpat zewnętrznych na ich przedpole. Skały fliszowe płaszczowin karpackich były niszczone, dostarczając do zbiornika okruchowy materiał sedymentacyjny.

\section{Budowa geologiczna rejonu wytypowanych do analizy złóż}

Złoże gazu ziemnego Tuligłowy związane jest z utworami badenu i sarmatu, a znajduje się w strefie nasunięcia Karpat fliszowych i jednostki stebnickiej na te właśnie utwory. Występuje ono między platformą epihercyńską a jednostką karpacko-stebnicką, która stanowi ,pokrywę” dla około ${ }^{2} / 3$ obszaru złożowego. Północna część obszaru złoża pozbawiona jest pokrywy, utwory sarmatu sięgają prawie powierzchni, do cienkiej pokrywy czwartorzędowej, a horyzonty gazonośne występują w dużym przedziale głębokościowym - od $550 \mathrm{~m}$ do $2950 \mathrm{~m}$. W budowie geologicznej regionu wyróżnia się cztery główne elementy strukturalno-tektoniczne $[2,3]$, przedstawione poniżej.

Fundament platformy epihercyńskiej - zbudowany jest, podobnie jak w znacznej części zapadliska przedkarpackiego, z utworów prekambru. Są to głównie łupki szare i szarozielone, twarde, zbite, bezwapniste, sfilityzowane, spękane, $\mathrm{z}$ cienkimi wkładkami piaskowców kwarcytowych, twardych, zbitych, bezwapnistych, jasnoszarych i szarych. Ich górną granicą jest powierzchnia erozyjna, która posiada bardzo urozmaiconą konfigurację. Powstała ona na skutek tektoniki dysjunktywnej oraz długotrwałych procesów denudacyjnych.

Miocen autochtoniczny - reprezentowany jest od badenu dolnego po sarmat dolny. W utworach tych odkryto wiele zasobnych złóż gazu ziemnego. Utwory miocenu zalegają bezpośrednio na utworach prekambru, które w omawianym rejonie tworzą trzon budowy geologicznej. Miąższość utworów miocenu autochtonicznego zmniejsza się w kierunku południowym na skutek warunków sedymentacji i również w rezultacie ich redukcji przez nasunięcie utworów jednostki stebnickiej i Karpat fliszowych. Ukształtowanie powierzchni podmioceńskiej odgrywa dużą rolę w formowaniu się utworów miocenu autochtonicznego. Kompleks miocenu autochtonicznego o miąższości 1800 $\div 2600$ m charak- teryzuje się bardzo dużą zmiennością udziału piaskowców w profilu pionowym, a także w rozprzestrzenieniu poziomym.

Jednostka stebnicka - zbudowana jest z różnorodnych pod względem litologicznym utworów reprezentujących niższe ogniwa badenu. Są to głównie łupki i mułowce szare i szaropopielate, przewarstwione pstrymi zlepieńcami zbudowanymi z różnorodnego materiału pochodzącego z fliszu karpackiego.

Karpaty fliszowe - są najwyżej położoną jednostką geologiczno-strukturalną. Buduje je szereg wąskich, antyklinalnych form strukturalnych typu skibowego, zaznaczających się na powierzchni występowaniem wąskich stref pstrego eocenu i łupków menilitowych.

Złoże gazu ziemnego Jarosław położone jest w południowo-wschodniej części przedgórza Karpat, w strefie, gdzie osady miocenu autochtonicznego zalegają bezpośrednio na zerodowanych utworach prekambru. Podłoże miocenu tworzą osady wykształcone jako łupki zielone i zielonoszare, często z przekładkami łupków wiśniowych sfilityzowanych oraz piaskowców kwarcytowych. Najstarszym ogniwem miocenu autochtonicznego są utwory badenu dolnego, które zalegając bezpośrednio na utworach podłoża, wypełniają jego zagłębienia i częściowo je wyrównują. Akumulacja gazu w rejonie Jarosławia związana jest z łupkowo-piaszczystymi utworami miocenu nadanhydrytowego. W wyniku prac stwierdzono tutaj na głębokości $700 \div 1500$ m występowanie gazu w 14 horyzontach. Charakteryzują się one, podobnie jak cały profil miocenu, dużą zmiennością litologiczną. Horyzonty najniższe i najwyższe wykształcone są w postaci osadów ilasto-łupkowych z cienkimi wkładkami i ławicami drobnoziarnistych piaskowców, które najczęściej rozwinięte są w facji niepełnej i wykazują przejście do mułowców. Skałę zbiornikową dla wszystkich horyzontów złoża stanowią piaskowce i mułowce.

\section{Złoże gazu ziemnego Tuligłowy - horyzont VIII}

Złoże gazu ziemnego Tuligłowy - horyzont VIII położone jest w południowo-wschodniej części Polski, w odległości około $15 \mathrm{~km}$ w kierunku NW od Przemyśla. Znajduje się ono w województwie podkarpackim, na terenie gminy Rokietnica w powiecie jarosławskim.

Odkrycie złoża gazu w horyzoncie VIII nastąiło w 1982 roku odwiertem P-220. Na złożu, w bezpośrednim jego sąsiedztwie, wykonano jeszcze 25 odwiertów poszukiwawczych, z których tylko pięć opróbowano w obrębie analizowanego horyzontu i uzyskują one przemysłowy przypływ gazu. Oprócz odwiertu P-220 eksploatację gazu z horyzontu podjęły jeszcze odwierty: T-3, T-11, T-14 i T-20. Z tej grupy pierwsze trzy odwiercono w latach 1983-1985. Odwiert T-20 został wykonany w 1987 roku, a do eksploatacji 


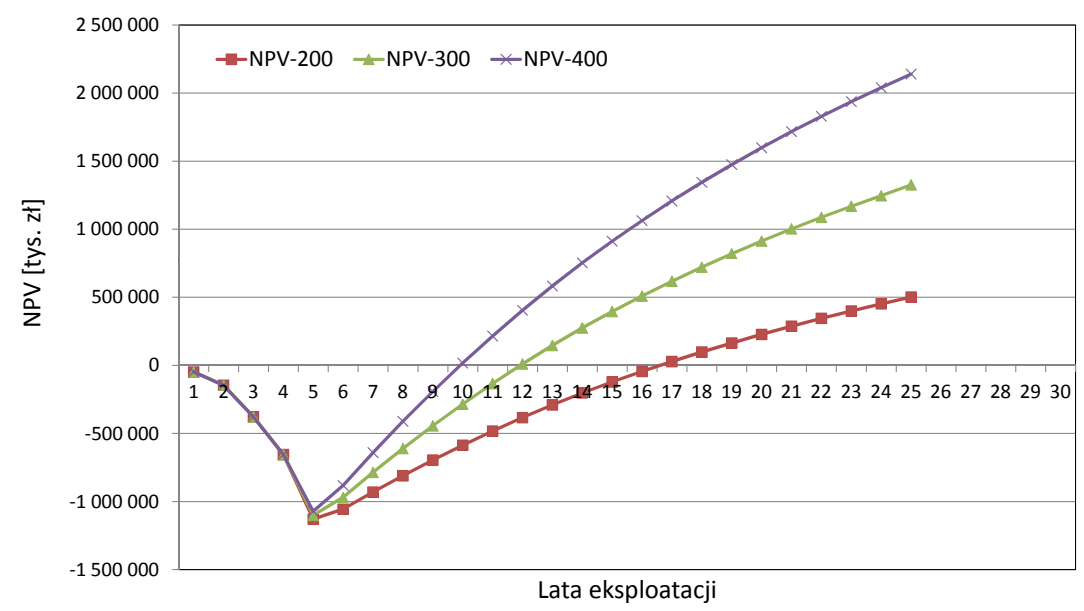

Rys. 1. Wykres NPV wykonany dla różnych wartości opłat za magazynowanie gazu, PMG Tuligłowy - horyzont VIII

włączono go w 1992 roku. Eksploatację złoża rozpoczęto w marcu 1983 roku. W pierwszych dwóch latach wydobycie wynosiło $8,8 \div 14,9 \mathrm{mln} \mathrm{m}^{3} /$ rok. W następnych latach w wyniku włączenia do eksploatacji nowych odwiertów zwiększono wydobycie gazu do wielkości mieszczącej się w granicach $89 \div 92 \mathrm{mln} \mathrm{m}^{3} /$ rok. Najwyższe wydobycie odnotowano w latach 1988-1989 i wynosiło ono $109 \div 116 \mathrm{mln} \mathrm{m}^{3} /$ rok. Gaz ziemny występujący w złożu należy do gazów wysokometanowych.

Przeprowadzone obliczenia wykazały, że w horyzoncie VIII złoża Tuligłowy można wytworzyć magazyn gazu o pojemności czynnej wynoszącej około $1100 \mathrm{mln} \mathrm{m}^{3}$, przy buforze całkowitym około $1130 \mathrm{mln}^{3}$.

Rys. 2. Mapa strukturalna stropu horyzontu VIII (1:25 000), ZGZ Tuligłowy

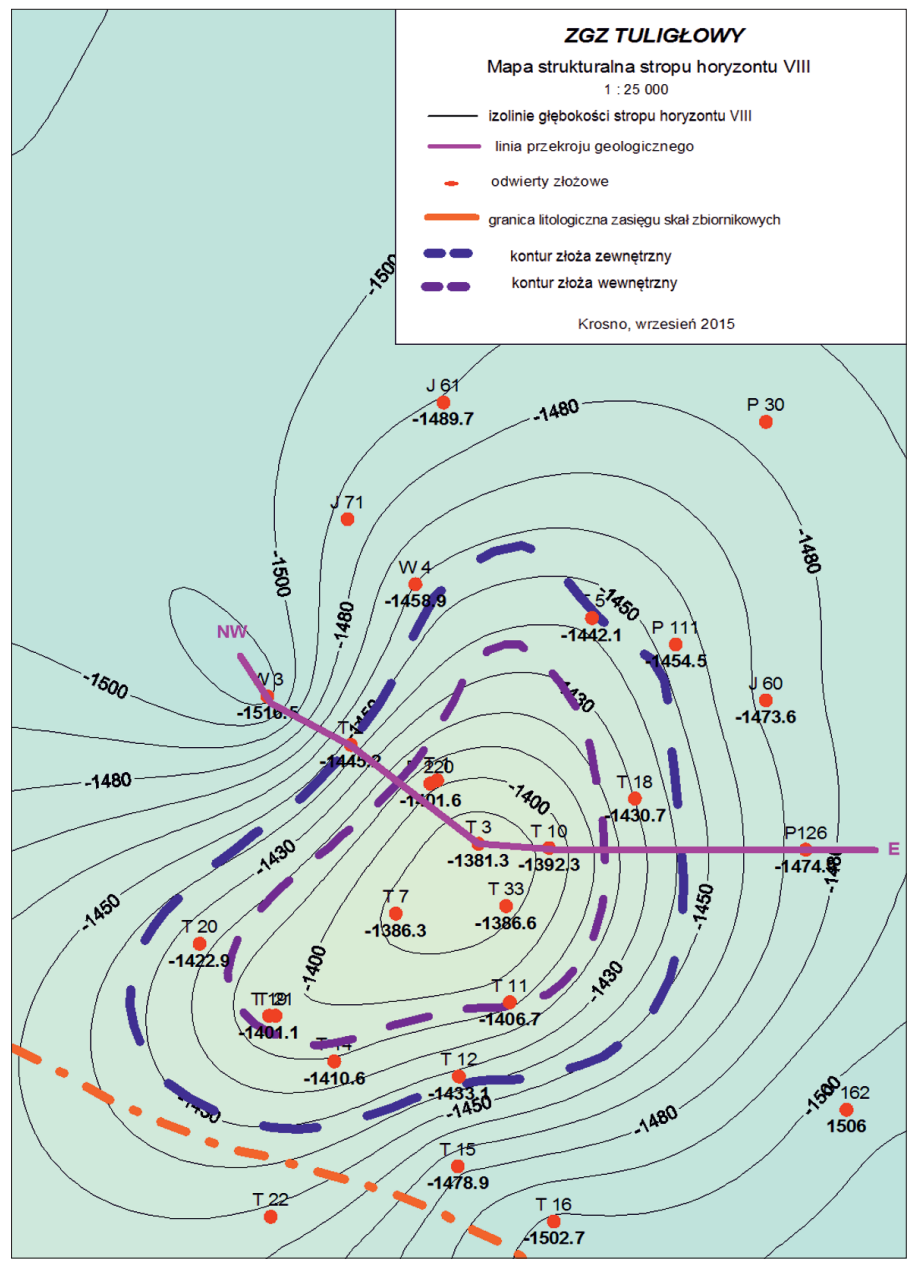

\section{Złoże gazu ziemnego Jarosław - horyzont C}

Złoże gazu ziemnego Jarosław - horyzont C położone jest w południowo-wschodniej części Polski, w województwie podkarpackim, w bezpośrednim sąsiedztwie miasta Jarosław, tak że jego południowo-wschodnia część o powierzchni $1,1 \mathrm{~km}^{2}$ zalega pod zwartą zabudową miasta.

Odkrycie pola gazowego Jarosław nastąpiło w 1958 roku odwiertem Jarosław-1. W latach 1964-1965 wykonano trzy dalsze odwierty. Po 11-letniej przerwie w pracach wiertniczych w 1977 roku przystąpiono do rozwiercania złoża. W okresie pięciu lat wykonano na złożu 34 odwierty, z których siedem uzyskało przemysłowy przypływ gazu $\mathrm{z}$ analizowanego horyzontu C. Eksploatację gazu z horyzontu C rozpoczęto w grudniu 1977 roku odwiertem J.20, a w 1978 roku włączono dwa następne odwierty: J.22a i J.26. W latach 80. włączono kolejne cztery odwierty: J.12, J.33, J.51, J.54, tak że pod koniec 1985 roku czynnych było siedem 
odwiertów. W początkowym okresie eksploatacji wydobycie gazu przy trzech czynnych odwiertach dochodziło maksymalnie do $35 \mathrm{mln} \mathrm{m}^{3} /$ rok. W okresie 1981-1989 przy liczbie czynnych odwiertów wahającej się od czterech do siedmiu wydobycie wynosiło w granicach $34 \div 42 \mathrm{mln} \mathrm{m}^{3} /$ rok. Gaz występujący w analizowanym złożu jest gazem wyso- kometanowym z niewielką domieszką węglowodorów cięższych $\mathrm{C}_{3}+$ w ilości $0,031 \mathrm{~g} / \mathrm{m}^{3}$.

Wykonane obliczenia wykazały, że w horyzoncie C złoża Jarosław można wytworzyć magazyn gazu o pojemności czynnej wynoszącej około $520 \mathrm{mln} \mathrm{m}^{3}$, przy buforze całkowitym około $470 \mathrm{mln} \mathrm{m}^{3}$.

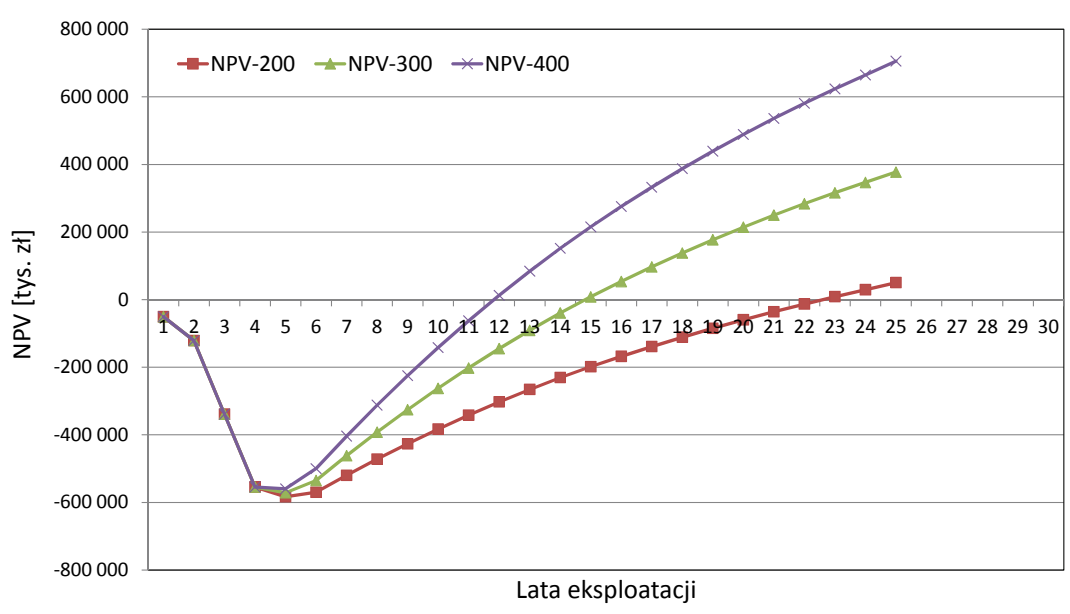

Rys. 3. Wykres NPV wykonany dla różnych wartości opłat za magazynowanie gazu, PMG Jarosław - horyzont C

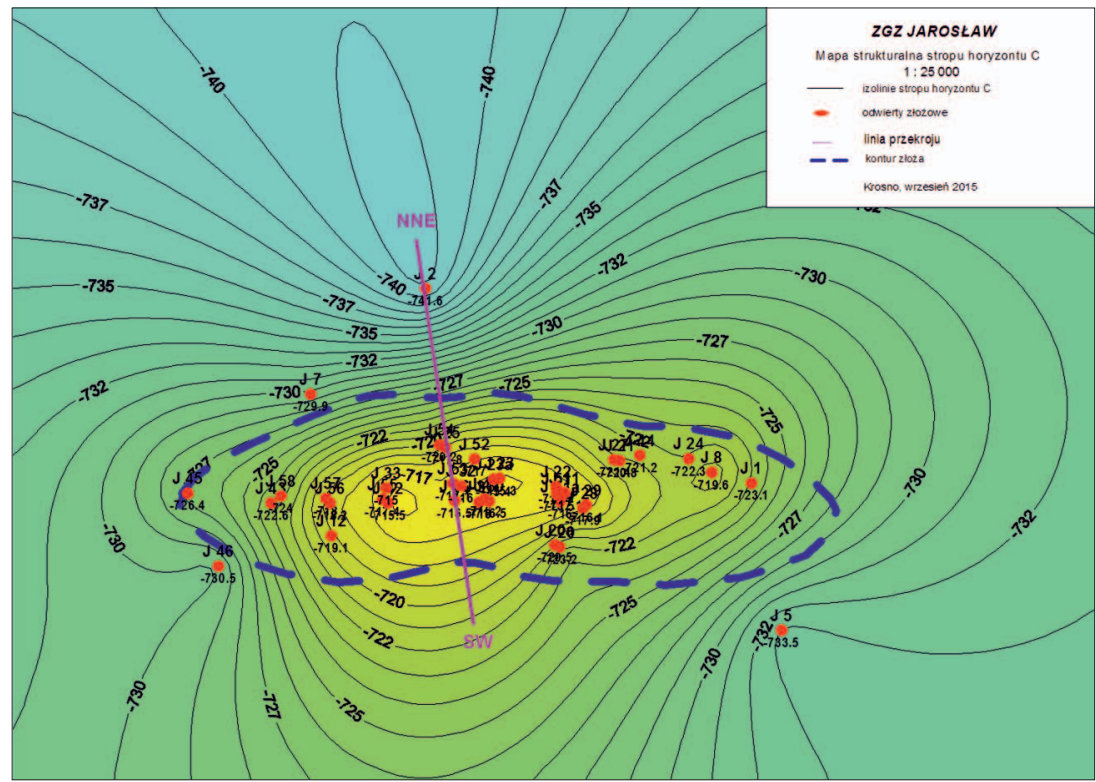

Rys. 4. Mapa strukturalna stropu horyzontu C (1:25 000), ZGZ Jarosław

\section{Złoże gazu ziemnego Jarosław - horyzont D}

Złoże gazu ziemnego Jarosław znajduje się w południowo-wschodniej części Polski, w bezpośrednim sąsiedztwie miasta Jarosław, i ciągnie się od północno-zachodniego krańca miasta na długości około 4,5 km w kierunku północno-zachodnim. Południowo-wschodnia część złoża o powierzchni około $1,1 \mathrm{~km}^{2}$ zalega pod zwartą zabudową miasta. Pole gazu ziemnego Jarosław odkryto w 1958 roku odwiertem Jarosław-1. W latach 1964-1965 powstały kolejne trzy odwierty, którymi udostępniono trzy horyzonty:
I, II, III. W 1977 roku, po 18-letnim okresie eksploatacji złoża, przystąpiono do jego rozwiercania. Ogółem w okresie pięciu lat wykonano 34 odwierty, którymi odkryto i udostępniono do eksploatacji kolejnych 11 horyzontów, w tym analizowany horyzont D. Przemysłowy przypływ gazu z tego horyzontu uzyskano w ośmiu odwiertach. Spośród wykonanych odwiertów na złożu 31 znajduje się w eksploatacji, a trzy są wykorzystywane do zatłaczania wody złożowej. W strefie pozakonturowej znajdują się cztery odwierty, 
Tablica 1. Szacunkowe podstawowe parametry PMG, jakie można osiągnąć w poszczególnych złożach

\begin{tabular}{|c|c|c|c|c|}
\hline Parametry PMG & Jednostki & $\begin{array}{c}\text { Tuligłowy } \\
\text { horyzont VIII }\end{array}$ & $\begin{array}{c}\text { Jarosław } \\
\text { horyzont C }\end{array}$ & $\begin{array}{c}\text { Jarosław } \\
\text { horyzont D }\end{array}$ \\
\hline Pojemność czynna & $\mathrm{mln} \mathrm{m}^{3}$ & 1000 & 400 & 420 \\
\hline Pojemność buforowa & $\mathrm{mln} \mathrm{m}^{3}$ & 900 & 600 & 530 \\
\hline Dotłoczenie gazu do buforu & $\mathrm{mln} \mathrm{m}^{3}$ & 725 & 106 & 63 \\
\hline Zakres ciśnień pracy, ciśnienie denne statyczne & $\mathrm{MPa}$ & $7,0 \div 16,0$ & $5,5 \div 9,0$ & $5,5 \div 10,0$ \\
\hline Wydajność odbioru PMG & $\mathrm{mln} \mathrm{m}^{3} /$ doba & 8,33 & 3,33 & 3,5 \\
\hline Konieczna liczba odwiertów & - & 19 & 42 & 22 \\
\hline Czas odbioru $T_{o d b}$ & dni & 120 & 120 & 120 \\
\hline Moc zatłaczania gazu do PMG & $\mathrm{mln} \mathrm{m}^{3} /$ doba & 6,67 & 2,67 & 2,8 \\
\hline Czas zatłaczania $T_{z a t}$ & dni & 150 & 150 & 150 \\
\hline Moc stacji sprężania gazu & $\mathrm{kW}$ & 13500 & 3750 & 4200 \\
\hline
\end{tabular}

które ze względu na negatywny wynik badań złożowych zlikwidowano.

Eksploatację złoża w horyzoncie D rozpoczęto pod koniec 1977 roku odwiertem J.22, w 1978 roku włączono dwa następne odwierty: J.20 i J.23, kolejne dwa, J.27 i J.55, włączono w 1981 roku, a następne trzy w okresie do 1985 roku, tak że od września tamtego roku na złożu czynnych było osiem odwiertów. Gaz występujący w złożu jest gazem wysokometanowym o zawartości węglowodorów $\mathrm{C}_{3}+$ wynoszącej $0,039 \mathrm{~g} / \mathrm{m}^{3}$.

Wykonane obliczenia wykazały, że w horyzoncie D złoża Jarosław można wytworzyć magazyn gazu o pojemności czynnej około $530 \mathrm{mln}^{3}$, przy buforze całkowitym okoto $470 \mathrm{mln} \mathrm{m}^{3}$.

Wstępna analiza geologiczno-złożowa pozwoliła stwierdzić, że w każdym z trzech analizowanych złóż można wytworzyć PMG, ale o różnych parametrach.

Można zauważyć dużą rozbieżność w pojemności czynnej i buforowej, dlatego wybór konkretnego złoża do konwersji na magazyn gazu powinien zostać dokonany na pod- stawie szacunkowej analizy finansowej, gdyż każde złoże posiada inne parametry [5].

Szacunkowa analiza finansowa wykazała, że wartości NPV obliczone dla wszystkich PMG w zakresie ceny za usługę magazynową zmieniającej się w przedziale $200 \div 400 \mathrm{zł}$ są dodatnie. Wyniki obliczeń NPV (finansowa wartość zaktualizowana netto dla inwestycji) oraz IRR (finansowa wewnętrzna stopa zwrotu inwestycji) wykonane dla poszczególnych PMG przedstawiają poniższe wykresy. Wartości NPV wyznaczone dla PMG Tuligłowy - horyzont VIII, Jarosław - horyzont C i Jarosław - horyzont D przy założeniu ceny za usługę magazynową wynoszącej $200 \mathrm{z} / 1000 \mathrm{~m}^{3}$ wynoszą odpowiednio: $715,8 \mathrm{mln}$ zł, 80,3 mln zł i 204,1 mln zł. Biorąc pod uwagę tylko wyliczenia NPV, należałoby stwierdzić, że najlepszą inwestycją jest budowa PMG w złożu Tuligłowy - horyzont VIII, o pojemności czynnej wynoszącej $1000 \mathrm{mln} \mathrm{m}^{3}$. Aktualne zużycie gazu w Polsce kształtuje się na poziomie około 15,8 $\mathrm{mld} \mathrm{m}^{3}$ rocznie. Obecna pojemność czynna magazynów w Polsce wynosi około $2,8 \mathrm{mld} \mathrm{m}^{3}$. W związku z tym budowa PMG o dodatkowej pojemności czynnej $1 \mathrm{mld}^{3}$ będzie wiązać

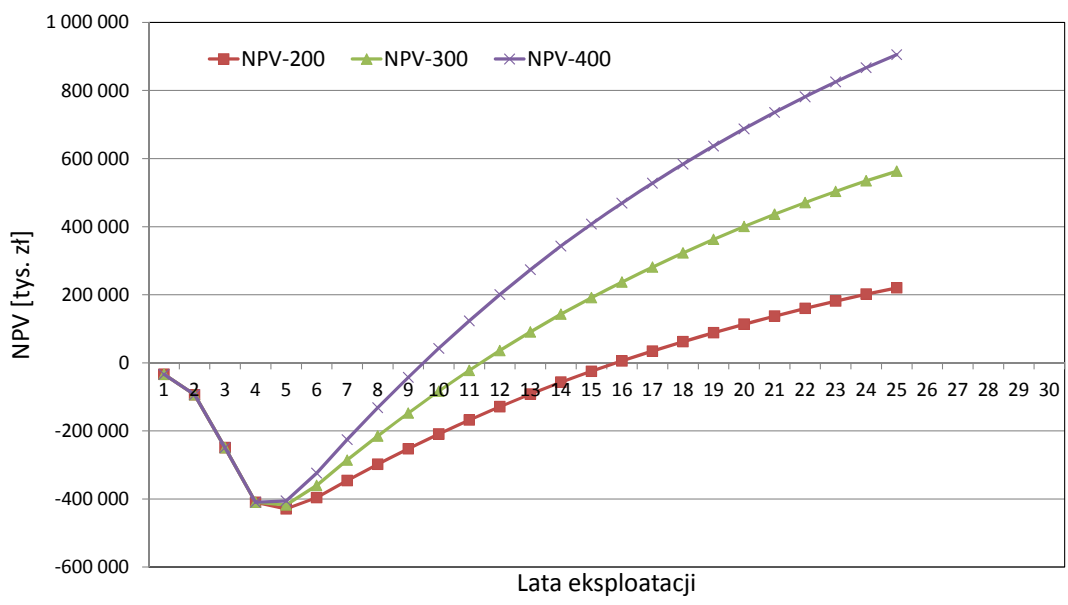

Rys. 5. Wykres NPV wykonany dla różnych wartości opłat za magazynowanie gazu, PMG Jarosław - horyzont D 
się z dodatkowym zapotrzebowaniem na gaz ziemny. Wyniki szacunkowej analizy wykazały, że w przypadku najniższej ceny świadczenia usługi magazynowej $\left(200 \mathrm{zt} / 1000 \mathrm{~m}^{3}\right)$ budowa PMG w złożu Tuligłowy - horyzont VIII zapewnia zakładaną stopę dyskonta (10\%). Natomiast budowa PMG w złożu Jarosław - horyzont C nie zapewnia wymaganej efektywności finansowej, gdyż IRR przy cenie minimalnej wynosi tylko $6,2 \%$, czyli inwestycja nie osiągnie zakładanej stopy dyskonta 10\%. Pod względem inwestycyjnym (NPV i IRR) atrakcyjność konwersji złóż Tuligłowy - horyzont VIII i Jarosław - horyzont D jest podobna. Jednakże należy pamiętać o tym, że złoże gazu Jarosław położone jest w strefie mocno zurbanizowanej, w związku z tym lokalni mieszkańcy mogą nie wyrazić zgody na budowę PMG.

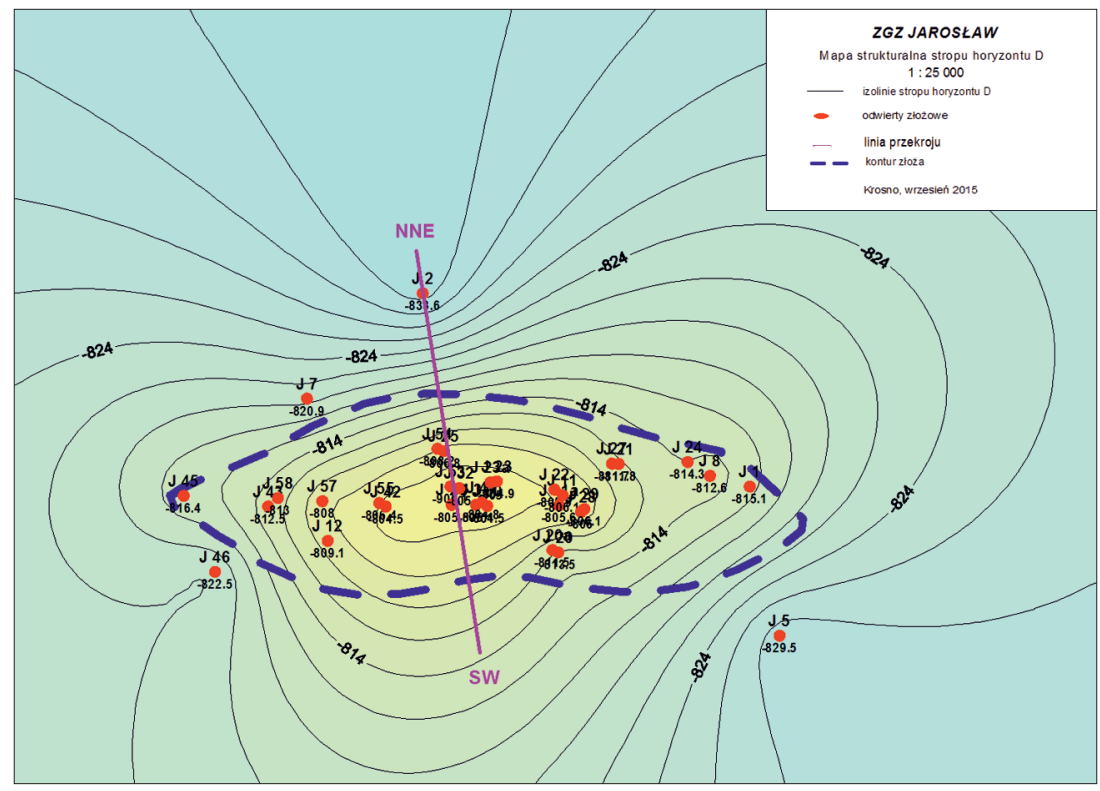

Rys. 6. Mapa strukturalna stropu horyzontu D (1:25 000), ZGZ Jarosław

\section{Podsumowanie i wnioski}

W ocenie przydatności struktur złóż gazu ziemnego do konwersji na podziemny magazyn gazu wzięto pod uwagę następujące kryteria $[10,11]$ :

- kryterium strukturalne - obiekt powinien stanowić pułapkę strukturalną lub stratygraficzną, odpowiednio wyniesioną ponad swoje otoczenie, aby mogła uzyskać odpowiednią pojemność magazynową,

- kryterium zbiornikowe - skały zbiornikowe muszą posiadać odpowiednią porowatość i przepuszczalność, aby zapewnić wymaganą pojemność magazynu i wydajność,

- kryterium szczelności - zbiornik magazynowy powinien być przykryty od góry skałami nieprzepuszczalnymi, aby gwarantować odpowiednie uszczelnienie,

- kryterium wielkości - zbiornik magazynowy powinien zapewnić odpowiednią pojemność czynną projektowanego PMG.
Wstępna analiza geologiczno-złożowa wykazała, że w każdym analizowanym złożu można wytworzyć PMG.

Wartości NPV obliczone dla PMG Tuligłowy - horyzont VIII, Jarosław - horyzont C i Jarosław - horyzont D przy założeniu minimalnej ceny za usługę magazynową (200 zł/1000 $\mathrm{m}^{3}$ ) wynoszą odpowiednio: 715,8 mln zł, $80,3 \mathrm{mln}$ zł i 204,1 mln zł.

Budowa PMG w złożu Jarosław - horyzont C nie zapewnia wymaganej efektywności finansowej, gdyż IRR przy cenie minimalnej wynosi tylko $6,2 \%$.

Pod względem inwestycyjnym (NPV i IRR) atrakcyjność konwersji złóż Tuligłowy - horyzont VIII i Jarosław - horyzont D jest podobna. Należy natomiast pamiętać o tym, że złoże gazu Jarosław leży w strefie mocno zurbanizowanej, w związku z tym ludność lokalna może nie wyrazić zgody na budowę PMG.

Prosimy cytować jako: Nafta-Gaz 2016, nr 2, s. 95-101, DOI: 10.18668/NG.2016.02.03

Artykuł nadesłano do Redakcji 10.11.2015 r. Zatwierdzono do druku 18.01.2016 r.

Artykuł powstał na podstawie pracy statutowej pt. Analiza wytypowanych złóż gazu ziemnego południowo-wschodniej Polski do konwersji na PMG - praca INiG - PIB na zlecenie MNiSW; nr zlecenia: 215/0031/15/01, nr archiwalny: KP-4100-31/2015. 


\section{Literatura}

[1] Dokumentacje geologiczne złóż gazu ziemnego Przemyśl-Tuligłowy, Maćkowice-Tuligłowy, Tuligłowy i Jarosław. PPN Jasło, PKGZ Sanok, PPNiG Jasło, ZPNiG Jasło i INiG-PIB Krosno.

[2] Dudek J. i in.: Dokumentacja geologiczna złoża gazu ziemnego Przemyśl-Tuligłowy. Dokumentacja przemysłowa, INiG Oddz. Krosno, 1998.

[3] Dudek J. i in.: Rozpoznanie warunków geologiczno-złożowych mioceńskich horyzontów gazowych. Dokumentacja, INiG Oddz. Krosno, 1988, nr 9/1/NP.

[4] Filar B.: Analiza wptywu wytworzenia zapasu obowiąkowego na koszt świadczenia ustug magazynowych. Nafta-Gaz 2010, nr 10, s. 903-907.

[5] Filar B. i in.: Analiza geologiczno-złożowa struktury Tuligłowy wykonana $w$ aspekcie wytworzenia $w$ niej podziemnego magazynu gazu. Dokumentacja, INiG Oddz. Krosno, 2002, $\mathrm{nr}$ 1048/01/KP.

[6] Jucha S., Zawisza L.: Petroleum Geology of Autochtonus Miocene in the Carpathian foredeep in Southern Poland. IAS, 12th Regional Meeting, Bergen 1991.

[7] Miziołek M. i in.: Określenie możliwości wytwarzania wielohoryzontowego PMG w mioceńskich złożach gazu ziemnego potudniowej czesści zapadliska przedkarpackiego. Dokumentacja, INiG Oddz. Krosno, 2003, nr 26/KP.

[8] Ney R., Burzewski W., Bachleda-Curuś T., Górecki W., Jakóbczak K., Słupczyński K.: Zarys paleogeografii i rozwoju litologiczno-facjalnego utworów zapadliska przedkarpackiego.
Prace Geol. Kom. Nauk Geol. PAN 1974, nr 82, Warszawa, Wydawnictwo Geologiczne.

[9] Oszczypko N.: Przebieg mioceńskiej subsydencji w polskiej części zapadliska przedkarpackiego. [W:] Peryt T. M. (red. nauk.): Analiza basenu trzeciorzędowego Przedkarpacia. Prace PIG 1999, t. 168, s. 209-230.

[10] Piesik-Buś W.: Analiza modelu geologicznego wytypowanego złoża gazu ziemnego do konwersji na PMG, z wykorzystaniem $\mathrm{CO}_{2}$ jako gazu buforowego. Nafta-Gaz 2010, nr 11, s. $1000-1007$.

[11] Piesik-Buś W., Zamojcin J.: Analiza przydatności wybranych złóż niecki zielonogórskiej do konwersji na PMG. Nafta-Gaz 2015, nr 3, s. 185-189.

[12] Zawisza L.: Hydrodynamiczne modelowanie basenów naftowych dla oceny ich perspektyw złożowych. Studia, Rozprawy, Monografie - Instytut Gospodarki Surowcami Mineralnymi i Energią PAN 2007, nr 140, Kraków.

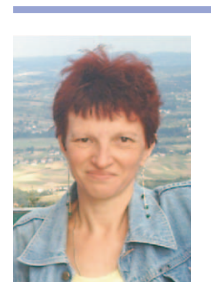

Mgr inż. Wacława PIESIK-BUŚ

Starszy specjalista badawczo-techniczny w Zakładzie Podziemnego Magazynowania Gazu.

Instytut Nafty i Gazu - Państwowy Instytut Badawczy ul. Lubicz 25 A

31-503 Kraków

E-mail: piesik@inig.pl

\section{OFERTA}

\section{ZAKŁAD PODZIEMNEGO MAGAZYNOWANIA GAZU}

Zakres działania:

- $\quad$ analiza struktur geologicznych złóż gazu ziemnego, ropy naftowej oraz obiektów zawodnionych, pod kątem możliwości ich przekształcenia w PMG;

- $\quad$ szczegółowa analiza warunków geologiczno-złożowych, ocena dotychczasowej eksploatacji złoża, warunków hydrodynamicznych, zdolności wydobywczych odwiertów;

- ocena stanu technicznego istniejącej infrastruktury w aspekcie jej wykorzystania w pracy PMG;

- $\quad$ wykonywanie cyfrowych modeli geologicznych PMG, złóż gazu ziemnego i ropy naftowej;

- $\quad$ wykonanie projektu budowy PMG;

- $\quad$ analiza dotychczasowej pracy istniejących PMG w celu optymalizacji parametrów dalszej eksploatacji magazynów na bazie symulacji komputerowej;

- opracowanie projektów prac geologicznych, dotyczących poszukiwania i rozpoznawania złóż gazu ziemnego i ropy naftowej;

- opracowanie dokumentacji geologicznych złóż ropy naftowej i gazu ziemnego;

- $\quad$ opracowanie programu optymalnej eksploatacji złoża, wydajności poszczególnych odwiertów, tempa sczerpywania itp.

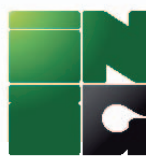

